\title{
Bir ‘Kültürel Aracı' Olarak Muzaffer Sarısözen ve Erken Cumhuriyet Döneminde 'Türk Halk Müziği’nin Yeniden İnşasındaki Rolü
}

\author{
İbrahim Yavuz YÜKSELSIN *
}

\section{Özet}

Erken Cumhuriyet dönemi müzik politikalarının üç temel amaç etrafında şekillendikleri görülür. Bunlardan birincisi, 'Ulusal Türk Musikisi'ni, sözde 'hasta', 'gayri milli' ve 'Bizans kırması' olarak tanımlanan Osmanlı dönemi 'Sanat Musikisi'nin etkilerinden kurtarmak; ikincisi, Anadolu halkının toplumsal etkinliklerinde, ritüellerinde işitilebilecek olan 'saf' ve 'milli' olarak kabul edilen müziklere ait örnekleri toplamak; üçüncüsü ise, Batılı/modern toplumlarla ulusötesi kültürel bağları kuracak çağdaş çoksesli, ancak 'milli’ bir sanat müziği yaratmak. Bununla birlikte her iki karşıt taraftaki (yerel-ulusal, geleneksel-modern, doğulu-batılı, folklorik-sanatsal vb.) kültürel referans noktalarını bilen ve söz konusu inşa sürecinde 'aracılık' (mediator) görevlerini üstlenecek uzmanlara ihtiyaç vardı. Bu makale, Muzaffer Sarısözen'i ve çalışmalarını kültürel aracılık (cultural mediation) ekseninde analiz etmenin yanı sıra Cumhuriyet dönemi müzik politikalarını eleştirel bir bakış açısıyla ele almayı da amaçlar.

Anahtar Sözcükler: Muzaffer Sarısözen, Kültürel Aracılık, Türk Halk Müziği, Erken Cumhuriyet Dönemi, Müzik ve Politika.

\section{Muzaffer Sarisozen as a 'Cultural Mediator' and His Role in the Reconstruction of 'Turkish Folk Music' in the Early Republican Period}

Abstract

The music policies of Early Republican Period of Turkey are shaped around three fundamental goals. Primary goal is to rescue 'the national Turkish music' from effects of artistic (maqam) music of Ottoman Period which is described as so-called 'sick', 'non national' and 'mongrel of Byzantine'. The second goal is to collect 'pure' musical examples that can be heard in the social events and rituals of Anatolian people. The third goal is to create a modern, polyphonic but 'national' art music that would constitute transnational cultural relations with modern/westerner societies. However, experts were required who knew cultural reference points of each opposite side (national-local, traditional-modern, folk-art etc.) and would undertake the role of the 'mediator' during reconstruction process. This paper aims to analyze Mustafa Sarisozen and his works in the scope of 'cultural mediation', and intends to evaluate the politics of music of the Early Republican period of Turkey from a critical point of view.

Keywords: Muzaffer Sarisozen, Cultural Mediation, Turkish Folk Music, The Early Republican Period, Music and Politics. 


\section{Giriş}

Birçok çalışmada (Balkılıç 2009; Hasgül 1996; Üstel 1994) vurgulandığı gibi İstiklal Savaşı'nın (1919-1922) ardından Osmanlı Imparatorluğu'nun yerine kurulan Türkiye Cumhuriyeti'nin (1923), Osmanlı Devleti ile olan kültürel bağlarının koparılıp yerine yeni ulusdevlet modeline uygun bir kültürel kimlik yaratmayı hedefleyen müzik politikalarının üç temel amaç etrafında şekillendiği görülür. Bunlardan birincisi, 'Ulusal Türk Musikisi'ni, sözde 'hasta', 'gayri milli' ve 'Bizans kırması' olarak tanımlanan Osmanlı dönemi 'Sanat Musikisi'nin etkilerinden kurtarmak; ikincisi, Anadolu halkının binlerce yıldan bu yana devam ettirdiği toplumsal etkinliklerinde, ritüellerinde işitilebilecek olan 'hakiki' müzikleri, 'milli' kabul edilen kültüre ait örnekleri toplamak; üçüncüsü, Batılı/modern toplumlarla ulusötesi (transnational) kültürel bağları kuracak çağdaş çoksesli, ancak 'milli' bir sanat müziği yaratmak. Çünkü 'muasır medeniyetler' seviyesine erişmesi hedeflenen yeni devletin siyasal sınırları içinde yaşayan 'modern birey'in tahayyül edilen kültürel özelliklerinden biri de ulusal ve çağdaş müziği anlayabilmesi olacaktır.

Gökalp’e (1972: 146-147) göre, ulaşılmak istenen 'muasır medeniyet' seviyesinin müziği, 'hasta' ve 'gayri milli’ olan Doğu müziği (Geleneksel Türk Sanat Müziği) yerine Batı müziği ile 'milli' olan 'halk' müziğinin kaynaşmasından doğacaktır. Bunun için gerekli formül ise oldukça basittir: halk müziğini toplamak ve Batı müziği biçemlerine göre armonize etmek. Toplamakla ilişkili bölüm bütünüyle folklorcuların, sonrası ise ‘musikişinasların' görevidir. Bu süreçte hemen her alanda yaşanan ulus-devlet merkezli ‘kültürel dönüşüm'ü (cultural transformation) merkezden periferiye, kentsel alanlardan köylere doğru uzanan bir sarmal olarak tanımlamak yanlış olmaz. Bununla birlikte, diğer tüm alanlarda olduğu gibi müzikte de, yerel-ulusal, geleneksel-modern, doğulu-batılı, folklorik-sanatsal vb. kavramsal karşıtıklar ile tanımlanabilecek kültürel farklııklar arasındaki ilişkilerin kurulması ve hedeflenen amaçlara ulaşılması için her iki uçtaki kültürel referans noktalarını bilen ve böylece söz konusu inşa sürecinde bu makalede 'kültürel aracılık' (cultural mediator) kavramı ile tanımlanan rolü üstlenecek uzmanlara ihtiyaç vardı. Ayrıca, hem Batı işi, modern, çoksesli müzik kültürünün hem de yeniden kurgulanan halk müziğinin tüm Türkiye’ye yayılmasını sağlayacak kanalları teşkil edecek kurumsal örgütlenmeler gerekiyordu. Bu nedenle, Erken Cumhuriyet Dönemi'nin ilk evresinde (1922-1934), ulusal çağdaş Türk müziğinin yaratılması ve derlenen halk müziği gereçlerinin 'Batı musikisi usulüne göre' armonize edilebilmesi için gerekli bilgi ve beceriye sahip müzik adamları yetiştirilmesine, bunlardan kadrolar oluşturulmasına ve eğitim kurumları kurulmasına öncelik verilir. ${ }^{1}$ ikinci evrede (1943-1952) ise, 'yeni musiki'nin benimsetilmesi ve kabul ettirilmesi için yaygınlaştırmaya yönelik çalışmalar içine girildiği görülür.

Erken Cumhuriyet döneminde kurulmuş ya da dönüştürülmüş en önemli kurumsal örgütlenmeler aşağıdaki diyagramda (Şekil 1) görülebilir.

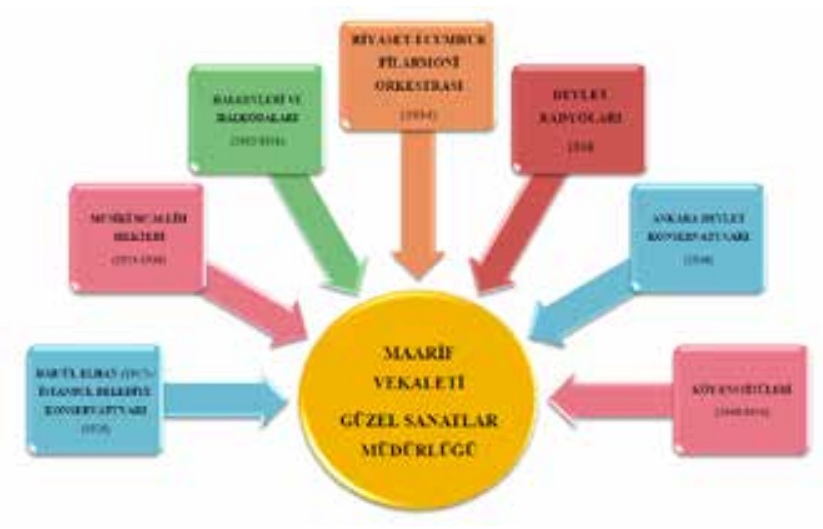

Şekil 1. Maarif Vekâleti’ne bağlı kurumlar.

Diyagramda (Şekil 1) görüldüğü gibi, Osmanlı döneminde kurulmuş (1917) olan Dar'ül Elhan (1926'da konservatuvar) ve Türk Ocakları (1932'de halkevi) gibi dönüştürme işlemine tabi tutulan ve Erken Cumhuriyet döneminde kurulan tüm kurumlar Maarif Vekâleti'ne (Milli Eğitim Bakanlığı) bağlı olup, Cumhuriyet'in ilk yıllarından başlayarak resmi kültür politikalarının gerektirdiği biçimde merkezi ve sıkı bir denetim altında yönetiliyorlardı. 
İkinci evreden başlayarak uygulanan politikaların en önemli sonuçlarından biri de, yeni kurulan devletin siyasal sınırları içinde yaşayan, ancak aralarında inanç, dil, müzik vb. bakımından birçok farklılıklar olan toplulukları 'Türklük' esasına dayalı tek bir ortak paydada bir araya getirecek yeni bir 'halk müziği'ni yeniden inşa etmek olmuştur. Bu süreçte önemli rol oynayan aktörlerin başında ise bu makalenin merkezinde yer alan Muzaffer Sarıözen (1899-1963) gelir.

Muzaffer Sarısözen, Maarif Vekâleti (Milli Eğitim Bakanlığı) tarafından planlanan ve 1937 'de Sivas'ta gerçekleştirilen birinci derleme gezisinden başlayarak, Anadolu'daki müziksel gereçlerin derlenmesi, arşivlenmesi ve Batı notasyonu ile çeviriyazımlarının yapılmasının yanı sıra, Ankara Radyosu'nda kurulan 'Yurttan Sesler' topluluğu ile 'Türk Halk Müziği' nin inşası sürecinde aşă̆ıda açıklanan birkaç 'kültürel aracılık' rolünü (aktarma, koruma, güçlendirme, dönüştürme vb.) birden üstlenmiş en önemli aktörlerden birisi olarak karşımıza çıkar.

\section{Kavramsal Model: 'Kültürel Aracılık’2}

Belirlenmiş toplumsal bağlamı dışında pek çok anlama gelebilen 'aracılık' terimi, genellikle birkaç çekirdek düşünceye ve kavrama işaret eder. ${ }^{3}$ Aracılık, en yaygın biçimde, iki uzak ya da karşıt kutup arasındaki orta noktayı işgal etme kabiliyetidir. Aracılık etmek demek, temelde "iki farklı konum arasında bir temas noktası, bir kesişim, iletişim ve diyalog alanı" sağlamaktır (Debrix 2003: xxi).

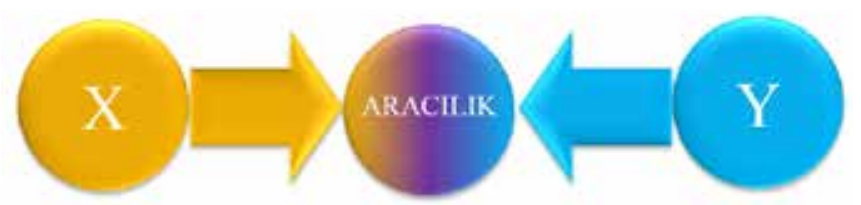

Şekil 2. İki farklı konumu (X ve Y) bağlantılayan aracılık alanı (Yükselsin 2011a: 223).

Aracılık, Runes'un (1970: 190) da vurguladığı gibi özellikle "aracısız etkileşimin mümkün olmadığı birbirinden oldukça farklı gerçeklik biçimlerine sahip sistemler için" gereklidir. Söz konusu sistemlerin kendi özgüllüklerini çoğu zaman kendi kültürel dizgelerini oluşturarak tanımladıkları gerçeği göz önüne alındığında aracıllğa duyulan gereksinim daha da önem kazanır. Burada kastedilen 'kültürel aracılık'tır. Çünkü kültürel aracılığın en temel dayană̆ı, kültürel nesnelerin kavranmasının bireysel ve yardımsız gerçekleşemeyeceği varsayımıdır. Bu nedenle bir anlam üretme aracı olarak müziğin kavranması için de her zaman kültürel aracılara ihtiyaç vardır (Yükselsin 2011a: 223).

Ronald Taft (1981: 53), Bochner'in kitabına katkısında kültürel aracıyı, "dil ve kültür bakımından farklı kişi ya da gruplar arasındaki iletişimi, anlayışı ve eylemi/ hareketi kolaylaştıran kimse" olarak tanımlar. Dolayısıyla kültürel aracı, bir bağlantı olarak hizmet vermek amacıyla bir ölçüde her iki kültüre de katılmak zorundadır. Bochner, bu durumu yani bir bireyin arayüz durumuna bulaştığı sıradaki ya da sonrasındaki değişimleri 'kültür öğrenme' (culture-learning) olarak adlandırır. ${ }^{4}$ Buna göre, 'kültürel aracı', en az iki farklı kültüre ilişkin bilgi, beceri ve aracılık deneyimlerine sahip kişi olarak tanımlanabilir.

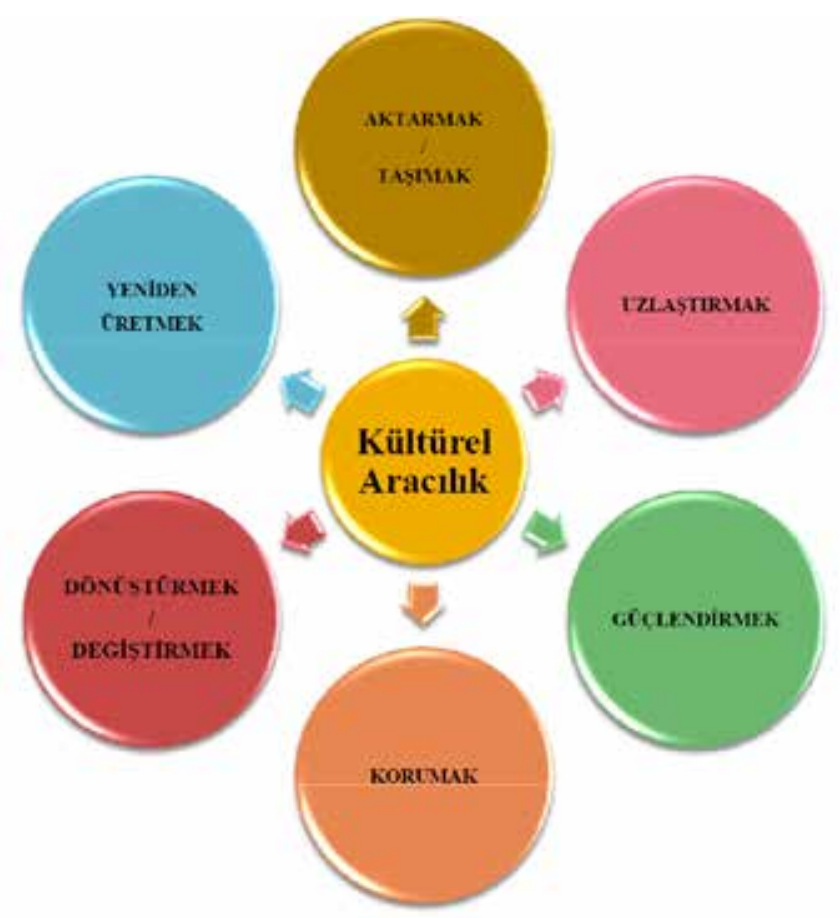

Şekil 3. Kültürel aracılığın görev ve amaçları (Yükselsin 2011a: 224). 
Yukarıdaki diyagramda (Şekil 3) görüldüğü gibi kültürel aracılığın, bazıları birbirine karşıt (örn. korumak ve dönüştürmek), belli başlı görev ve amaçları vardır. Bir kültürel aracılık görevi olarak 'aktarmak/taşımak' (transferring/transporting), bir kültürün kısmen ya da bütünüyle bir yerden bir yere taşınması biçimindeki mekânsallığa ya da kültürel bellek alanlarında (bireylerin biyolojik bellekleri ya da fiziksel mekânlarda) saklanarak geçmişten geleceğe aktarılması biçiminde zamansallığa vurgu yapar. 'Uzlaştırmak' (reconciliation), iki farklı kültürel varoluş düzeyinin her birinin karşısındakinin kültürüne duyduğu hoşgörüyü arttırmayı olduğu gibi, iki kültürün yeni bir varoluş düzeyinde, yeni bir ortak kültürel paydada buluşabilmelerini de amaçlayabilir. Bir kültürün devamlılığı ve dayanıklılığı elindeki 'kültürel sermaye'nin gücüne bağlıdır. Bu sermayenin arttırılması, yani 'güçlendirme' kültürel aracılık olmadan mümkün değildir. 'Güçlendirmek' (reinforcement), ya sahip olunan kültürel dizgeye göre yenilerinin yaratılması ya da başka kültürlere ait olanların sahip olunan dizge referans alınarak dönüştürülmesi yoluyla sağlanır. Kültürel aracıllğın 'koruma' (protection/preserving) görevi, çoğu zaman bir kültürün işaretleyici özelliklerini ve nesnelerini onun adına muhafaza etmek ya da dış etkilere kapatmak biçiminde olabilir. 'Dönüşüm' (transformation), başka bir çevreye (mekânsal, kültürel, toplumsal vb.) ait bir özne ya da nesnenin (bir birey, kültürel unsur vb.) yeni bir çevre içinde yabancı olarak algılanmadığı ya da yabancılığının farkına varılmadığı zaman mümkündür. Dönüşüm iki yolla gerçekleştirilir: Uyarlama/adaptasyon (adaptation) ve bireştirme/sentezleme (synthesizing). Bir kültürü 'yeniden inşa'ya (reconstruction) yönelik aracılık ise, kültürün devamlılığının yanı sıra dinamiklik ve değişebilirlik özelliklerine vurgu yapar. Çünkü ister koruma, ister dönüştürme, isterse güçlendirme amaçlı olsun her kültürel aracılık etkinliği, öznesi olan kültürün yeniden ve yeniden üretilmesini gerekli kılar (Yükselsin, 2011a: 224, 225).

\section{Kültürel Aracı Olarak Sarısözen}

Muzaffer Sarısözen'i halk müziğinin sistematik olarak derlenmesi, kurgulanması ve yaygınlaştırılmasında oynadığı aracılık rollerini ortaya çıkaran etkenleri, bir başka söyleyişle kültürel aracıya nasıl dönüştüğünü anlamakiçin, Bochener'in (1981:2) “kültür öğrenme” olarak adlandırdığı kültürlenme, yani yetişme sürecine bakmak gerekir. Bu kültürlenme sürecinin ilk evresi, çocukluğundan Dâr'ül Elhân'ın 1926 yılında gerçekleştirdiği ilk derleme gezisine kadar geçen süre oluşturur.

1899'da, Sivaslı, eğitimli, saygın ve müziksever bir ailenin en küçük çocuğu olarak doğan Sarısözen'in hem makamsal (Klasik Türk Müziği) hem de modal (Halk Müziği) müzik kültürleri içinde yetiştiği görülür (aktaran Altınay, 1993: 1; Elçi, 1997: 23). Müzikle yakından ilgilenen aile üyelerinin Nakşibendî olmaları nedeniyle o dönemde çalgı çalmak hoş karşılanmadığı için ud, keman, bağlama ve tanbur gibi çalgılar evin gizli bir bölmesinde saklanıyordu (Elçi, 1997: 23'den). Böyle bir ortamda dünyaya gelen Sarıözen'in, Ali Rıza Avni'nin kendisi ile yaptığı bir görüşmede, müzikle ilişkilenmesinin konuşmaya başladığı ilk günler kadar eski olduğunu, annesi ve ağabeylerinin kendisini halk müziğine karşı özel bir ilgi geliştirmesini sağladıklarını, büyüdükçe ağabeyleri ile gittikleri sazlı ve hikâyeli kahveler ve köy hayatının etkisi olduğunu vurgulaması bunu destekler (aktaran Elçi, 1997: 23). Altınay’ın (1993: 1) aktardıklarına göre bu dönemde Sarısözen hem ud hem de bağlama çalmaktadır. ${ }^{5}$

Kurtuluş Savaşı'nın ardından 1922-23 yılında öğretmenliğe başlayan Sarıözen'in 'Kültürel Aracı' olmasıyla sonuçlanacak kültürlenme sürecinin ikinci evresi, aslında 1926 yılında Dâr'ül Elhan (kuruluş tarihi 1917) tarafından gerçekleştirilen ilk derleme gezisi ile başlar. 31.7.1926-20.9.1926 tarihleri arasında (Altınay, 2008: 2) düzenlenen gezide Sivas'a giden Derleme Heyeti, Muzaffer Sarısözen'deki müzik yeteneğini keşfeder ve Derleme Heyeti'nin başkanı Yusuf Ziya Demircioğlu daha sonra İstanbul Belediye Konservatuvarı adını alacak Dâr'ül Elhan'da okuması için kendisini davet eder. Kendi doğduğu toprakların müzik kültürünü (modal-makamsal müzik, bağlama, ud icrası) öğrenmiş olan Sarısözen Dâr'ül Elhan'a gönderilerek Batı sisteminde (nota öğrenimi, 
keman icrası) eğitim görür. ${ }^{6}$ Dâr'ül Elhan'daki eğitiminin ardından yeniden Sivas'a dönen Sarısözen, önce 'Sanatlar Okulu’nda ardından Sivas Lisesi’nde müzik öğretmenliğine atanır (Şenel, 1999: 109; Altınay, 2008: 2; Elçi, 1997: 24).

Sarısözen bu dönemde kültürel aracılık ile ilişkilendirebileceğimiz ve bir anlamda uzmanlaşma deneyimleri olarak örneklendirebileceğimiz iki somut projenin gerçekleşmesinde rol oynar. Bunlardan birincisi kendisi gibi bir müzik öğretmeni olan Hüseyin Kaya ile birlikte Sivas'ta Garp Musikisi (Batı müziği) eğitimi vermek üzere ‘ilk Musiki Mektebi’ni kurmasıdır. 0 dönemde yayımlanan bir çalışmada okulun kuruluşu şöyle tanımlanıyor: "Garp Musikisinin önemi henüz layıkıyla anlaşılamadığı bir zamanda Anadolu'nun tam göbeğinde böyle bir kurumun canlanmış olması, ilim gidişi bakımından müteşebbisleri takdirle kaydettirecek bir hadise teşkil ediyor." (aktaran Altınay, 1993: 2). Tüm çabalara karşın okulun ömrü pek uzun olmasa da, Sarısözen ve Kaya'nın Sivaslı gençlere Batı müziğini/ kültürünü öğretmeleri dikkat çekicidir.

Sarısözen'in içinde yer aldığı ikinci proje, 'yerel olan'ın korunmasına yöneliktir. 1930 Eylül'ünde Sivas'a atanan Ahmet Kutsi Tecer ile birlikte 1931 yılında 'Halk Şairleri Koruma Derneği'ni kurarlar ve aynı yılın sonunda (5 Kasım) Halk Şairleri Bayramı'nı düzenlerler (aktaran Altınay, 1993: 3). Bu bayram, daha sonra ulus-devlet projesinin seçilmiş halk müziği sanatçısı olarak radyodan, köy enstitülerine kadar birçok kurumda görev almış ve 'otantik', 'yerel', 'bozulmamış' halk müziğinin temsilcisi olarak simgeleştirilmiş âşık Veysel Şatıroğlu'nun keşfedildiği etkinlik olmasıyla da oldukça önemlidir. Ayrıca, yapılan etkinlik sonrasında çıkarılan broşürde Sarısözen, notaları ile birlikte 'Sivas Halayları' başlıklı bir yazı yayınlar (Elçi, 1997: 27).

Görüldüğü gibi, önce kendi yaşadığı coğrafyanın kültürü içinde (tek kültürlü) yetişen, ardından İstanbul Belediye konservatuvarındaki eğitimi sonrasında Sivas'ta gerçekleştirdiği projelerle hem Batılı, kentli ve modern hem de yerel ve kırsal kültüre ilişkin deneyimleriyle, bilgi ve becerilerini en azından iki-kültürlü olarak geliştiren Sarısözen, yeni ulus-devlet projesinin beklentilerini karşılayacak bir 'kültürel aracı'ya dönüşmüş̧ür.

Şekil 4'te de görülebileceği gibi, Muzaffer Sarısözen inşa edilmekte olan “Türk Halk Müziği” ne gereç oluşturacak halk şarkılarının ve ezgilerinin hem derlenmesi ve arşivlenmesi, hem Cumhuriyet dönemi ideolojisi ve Batı normlarına göre yeniden kurgulanması, hem de kurgulanan yeni halk müziğinin radyo aracılığıyla yaygınlaştırılması aşamalarının tümünde de görev almıştır.

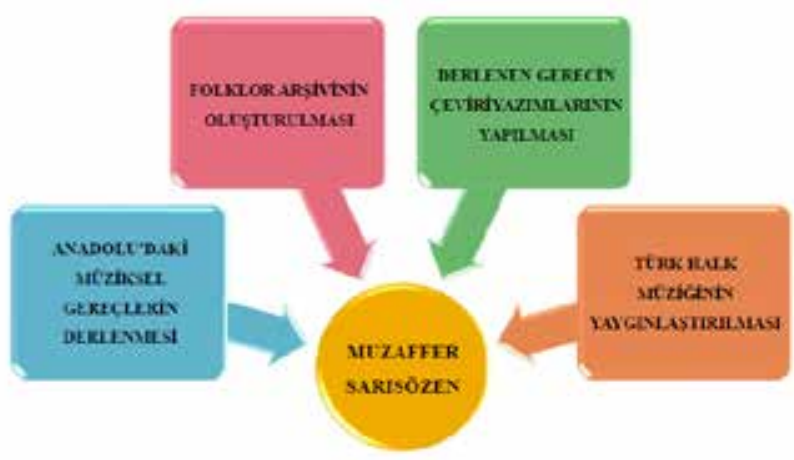

Şekil 4. M. Sarısözen'in Türk Halk Müziği'nin inşası sürecinde üstlendiği görevler.

\section{'Yerel'in Toplanması ve Dönüştürülmesi}

Muzaffer Sarısözen'in Sivas'ta kültürel aracılık ile ilgili deneyimleri yaşadığı dönemde yeni Türkiye Cumhuriyeti'nin resmi kültür politikaları çerçevesinde önemli kararlar alınmış ve uygulamaya geçirilmişti. 1931'de kapatılan Türk Ocakları'nın yerine 1932'de Halkevleri kuruldu. 1 Kasım 1934'de Atatürk'ün mecliste yaptığı konuşmanın hemen ardından Musiki İnkılâbı Komisyonu'nu oluşturuldu ve Türk müziği radyolardan yasaklandı. Yine aynı yıl Riyaset-i Cumhur Filarmoni Orkestrası kuruldu. 1936 yılında gerçekleştirilen uygulamalara bakıldığında, o döneme dek TTTAŞ (Türk Telsiz Telefon Anonim Şirketi) tarafından işletilen Radyo'nun devlet radyosuna dönüştürülmesi, Türk müziğinin radyolarda yeniden başlatılması, Ankara Devlet Konservatuvarı'nın kurulması ve aynı yıl içinde Bela Bartók'un Türkiye'ye gelerek A. Adnan Saygun ile Adana'da 
alan çalışması gerçekleştirmesi gibi, müzik reformuna yönelik çalışmaların hayata geçirildiği görülür.

Bartok'un gelişine kadar Seyfettin ve M. Sezâi Asaf kardeşlerce (1925), İstanbul Konservatuvarı'nca (eski adıyla Dâr'ül Elhan) 1926-29 yılları arasında ve Türk Halk Bilgisi Derneği'nce (1929 ve 1931'de) gerçekleştirilen yerinde derleme çalışmaları dışında halk müziğine ilişkin başkaca bir derleme çalışması yapılmamıştı. ${ }^{7}$ Bu nedenle Bela Bartók'un Saygun ile birlikte gerçekleştirdiği alan araştırmasına dayalı model çalışma Kurt Reinhard'ın da (1992: 220) belirttiği gibi “Türk müzik folklorunun gelişmesinde önemi yadsınamayacak bir kilometre taşıdır". Ankara Üniversitesi Macar Dilleri profesörü László Rásonyi, M. Ragip Gazimihal ve A. Adnan Saygun'un girişimleri sonucu, Ankara Halkevi'nin davetiyle Türkiye'ye gelen Bartók'un davet edilmesinin en önemli nedeni, Saygun'a göre "tecrübeli bir halk müziği derleyicisinden uzman danışman olarak yararlanmaktır" (Yükselsin 2011b: 254'den). Kısa bir süreye (18-25 Kasım 1936) sığdırılan bu alan çalışmasında, Bartók ve Saygun için Maarif Vekâleti (Milli Eğitim Bakanlığı) tarafından görevlendirilen Necil Kazım Akses ve Ulvi Cemal Erkin de gözlemci olarak bulundular. Akses ve Erkin'in gözlemci olarak bulunmalarının nedeni açıktır aslında: 'Usta' Bartók'dan derleme işinin inceliklerini öğrenmek. Nitekim Saffet Arıkan'ın Maarif Vekili olduğu dönemde, aynı yıl henüz kurulmuş olan Ankara Devlet Konservatuvarı'nca derleme çalışmalarının daha sistematik yapılması ve bir folklor arşivi kurulması kararlaştırılmıştı. Böylece derleme çalışmalarının nasıl yapııdığını yerinde izlemek üzere görevlendirilen Ankara Devlet Konservatuvarı kadrosundaki Akses ve Erkin ertesi yıl 17 Ağustos 1937'de, Hasan Ferit Alnar, Halil Bedii Yönetken ve teknisyen Arif Etikan'ın da görev aldığı ekiple Sivas, Elazığ, Erzincan, Erzurum, Gümüşhane, Trabzon ve Rize illerinde yürütülen ilk derleme çalışmasına başladılar. Bu derleme gezisinin Sivas ayağında ekibe Ahmet Kutsi Tecer'in tavsiyesi ile Muzaffer Sarısözen'in de katılması (Altınay, 1993: 3; Elçi, 1997: 27), aynı zamanda Sarısözen'in Türk Halk müziğinin inşası sürecindeki baş aktörlerden biri olacağı sürecin de işaretleyicisidir. Sarıözen, Sivaslı oluşu, bölgeyi ve halk müziği ustalarını iyi tanımasıyla bu ilk derlemede önemli katkılar sağlar. Sarısözen, Sivas'ın müzik ve halk oyunları hakkında ayrıntılı bilgilere sahip olmanın yanı sıra Ruhsatî, Veysel, Verâni, Emrah, Sümmânî ve diğer âşıkların edebiyatlarını da iyi tanımaktadır. Sivas ağzını iyi bildiği için âşıkların söylediklerini iyi anlar ve doğru biçimde kaydeder. Aynı başarıyı bundan sonra gidilen diğer yerlerde de sergiler (Elçi, 1997: 27).

Sarısözen, bu ilk derleme çalışmalarında gösterdiği başarı üzerine ertesi yıl (1938) Ankara Devlet Konservatuvarı Folklor Arşivi Şefliği'ne atanır (Altınay, 1993: 4) ve böylece asıl 'kültürel aracılık' rolü başlar. Sarısözen, Ankara Devlet Konservatuvarı tarafından 1937'den 1952 yılına kadar düzenlenen derleme gezilerinin tümünde görev alır. Sarısözen'in beşinci derleme gezisinden (1941) başlayarak birçoğunu Halil Bedii Yönetken ve Ali Razı Yetişen ile yürüttüğ̈̈ 8 derleme gezileri sonucunda konservatuvar folklor arşivinde 10.000'e yakın müziksel gereç toplanır ve derlenen gereçler tele, muma ve taş plaklara kaydedilir.

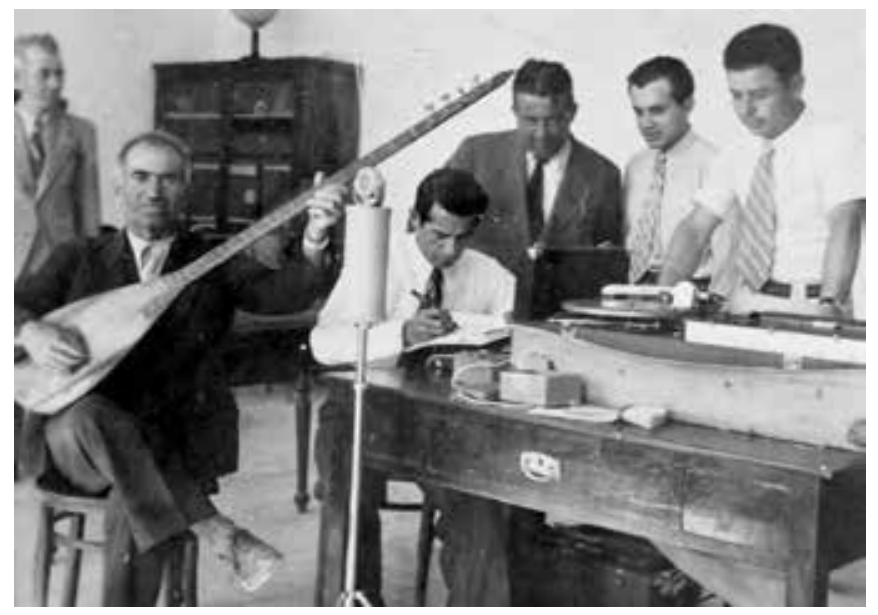

Fotoğraf 1. Muzaffer Sarısözen, M. Ragıp Gazimihal, Rıza Yetişen derleme çalışmasında, 1939/40.

Derleme gezilerini incelediğimizde, kültürel aracılık bağlamında üç ana amaca hizmet ettiğini görürüz. Bunlardan birincisi, saf/öz halk müziğini tınısal içeriği ile birlikte icra edildiği gibi fonografa kaydederek 
Ankara'daki folklor arşivi belgeliğine aktarmak ve böylece radyo gibi kitle iletişim araçlarının yaygınlaşması ile yok olma tehlikesi altında olduğu düşünülen yerel müzik kültürlerini geleceğe taşımak üzere muhafaza altına almaktır. Bu nedenle köylülerin (uzman müzisyenler) ya da profesyonel müzisyenlerin belleklerinde yer etmiş sözel ve çalgısal gereçlerin içeriklerine ve kültürel özelliklerine ilişkin malumatlar, ileride değerlendirilmek üzere derleme fişleri ile saptanıp yerinde kaydediliyordu. İkincisi, modern/Batılı tekniklerle işlenmiş milli çoksesli Türk müziğinin yaratılması için gereç oluşturmaktır. Sonuncusu ve bu makalede tartışıldığı üzere, tüm Anadolu halk müziklerinin envanterini çıkartarak, bu envanterden seçilenlerden kurulu yeni ulus-devlet modeline uygun bir 'Türk Halk Müziği' yaratmaktır.

‘Kültürel Dönüşüm' (cultural transformation) olarak adlandırdığımız bu süreçte yapılan çalışmaların ilk ayağı ise yazılı olmayan kültürlerin yazılı kültüre dönüştürülmesidir. Ancak aşağıda tartışılacağı üzere yazılı kültüre dönüştürmede kullanılan yazı -müzik yazısıolarak Batı kültürlerinde kullanılan ve tonal bir sisteme uygun olan Nota yazısının Türk müziğine uyarlanarak kullanılması birçok sakıncayı ve yanlışlığı da beraberinde getirmiştir. Bununla birlikte resmi olarak, Donizetti'nin Yeniçeri Ocağı ile birlikte lağvedilen Mehterhane'nin yerine kurulan bandonun başına geçmesinden (1828) sonra kullanılmaya başlanan ve Cumhuriyet döneminin başlangıcında ilk olarak Geleneksel Türk Sanat Müziği'nin yazııması için uyarlanan Batı notasından başka, ortak olarak bilinen ve kullanılan bir müzik yazısı olmadığı düşünülürse, elde başka bir seçenek olmadığı ve bu durumun kaçınılmaz olduğu daha iyi anlaşılır. Ancak dönüşüm sürecinde meselenin yalnızca Batı notasının kullanılmasına indirgenemeyeceğini de vurgulamak gerekir.

\section{Kültürel Müdahale: Türk Halk Müziği'nin İnşası / Restorasyonu}

Cumhuriyet döneminin reformcu atılımları içinde yerel kimliklere dokunulmayacağını düşünmek hata olurdu.
Çünkü giriş bölümünde de belirtildiği gibi, Cumhuriyet'le birlikte uygulamaya geçirilen projenin ana hedefi, misak-ı milli sınırları içindeki halkı gündelik yaşam ve giyim kuşam tarzından yemek adabına, gündelik yaşam alışkanlıklarından toplumsal davranış kurallarına varıncaya kadar her anlamda dönüştürmekti. Dolayısıyla modernleşme/Batılılaşma ekseninde yürütülen çalışmaların bir sonucu, derlenen yerel kültürlerin Batının kültürel normlarını ve tekniklerini öğrenmiş kadrolarca yeniden kurgulanarak ait oldukları topluluklara 'milli kültür' olarak sunulması oldu. Yerel müzik kültürlerine ait gereçlerin (köylü şarkıları, dansları) toplanıp yeniden işlendikten sonra halkevleri ve radyo aracılı̆̆ ile tüm ülkeye yayılarak ortak bir ‘milli’ kültürü (Türk Halk Müziği, Türk Halk Oyunları/Dansları) paylaşan bir millet/ulus yaratılması hedefleniyordu. Bu durum halk müziğinin inşasında yerel müziklerin dil, ezgi, tartım/usul, çalgılar, seslendirme biçemi vb. birçok özelliğine "yetkili uzmanlar" (Ediboğlu, 1947: 10) tarafından müdahale edilmesi meşru kabul edildi.

Halk müziğinin yeniden inşasında izlenilen yol ile dil reformunda izlenilen yol arasındaki benzerlikler dikkat çekicidir. Dil reformu ve Güneş-dil teorisinde izlenilen yol bir anlamda ulusal/milli olarak tanımlanabilecek özelliklere sahip yeni ve üniter bir 'halk müziği' üretilmesinde de model oldu. Dil reformu ile milli kimliğin inşasının vazgeçilmez bileşenlerinden biri olarak görülen tek tip ve homojen bir dil yaratılması gerekiyordu. Çünkü Kurtuluş Savaşı sonrasında çizilen yeni sınırlar içinde birbirinden farklı birçok dil (Türkçe, Kürtçe, Rumca, Ermenice, Lazca, Romanca, Arapça, Arnavutça, Bulgarca, Gürcüce, Adigece vb.) konuşuluyordu. Cumhuriyet öncesinin 'Osmanlıca' olarak da adlandırılan resmi dili ise Türkçe, Arapça, Farsça dillerinin bileşkesi olan bir dildi. Bununla birlikte, Cumhuriyet döneminin söylemi, halkın gündelik konuşmasında bu dilden çok farklı bir dil (öz-Türkçe) kullanıldığını iddia ediyordu. Cumhuriyet rejiminin belki de en önemli avantajı (aynı zamanda yanılgısı) ise bu toplulukların birçoğunun okuma-yazma bilmemesiydi. Eğitim ve harf devrimi ile birlikte yeniden 
inşa edilen Türkçe'nin tüm topluluklara öğretilmesinin de daha kolay mümkün olacağı düşünülüyordu. Bu yolla Osmanlıca denilen eski Türkçe içindeki tüm Arapça ve Farsça kelimelerin atılmasının yanı sıra, Türk Dil Kurumu tarafından yeni sözcükler türetilmesi yoluyla arı bir Türkçe oluşturularak tüm toplulukların bu dili konuşmaları sağlanacaktı. Bu toprakların tüm topluluklarının konuşacağı resmi dili Türkçe, müziği ise 'Türk Halk Müziği' olacaktı. Dolayısıyla dil reformu, çoğu zaman sözel halk müziğinin dilini de yeniden formüle etmeyi gerektirdi. Örneğin, Stokes'un (1998: 104) aktardığına göre, TRT repertuvarında bulunan ve "Prahoda mindim sürdüm seyrana" sözleri ile başlayan bir türkü "Gemilere bindim sürdüm Samsun'a” şeklinde değiştirilmiştir. Zira tren anlamına gelen prahod sözcüğü Rusça'dır ve bu şekilde kabul edilmesi mümkün değildir. Tren sözcügünnün öz Türkçe karşıllğı da bulunmadığından, tren yolculuğu gemi yolculuğu ile değiştirilmiştir. Hasgül (1996: 43) de 'seyran' sözcüğünün Arapça olmasından dolayı Samsun ile değiştirildiğini aktarır. Sonraki bir değişiklikte de yolculuğun son durağı Bakü yerine lğdır olmuştur.

Cumhuriyet dönemi müzikçilerinin halk müziğini çoksesliyapmakvearmonize etmek, türkülerikoroyauygun hale getirmek gibi halk müziği merkezli uygulamalarına bakıldığında ezgilere müdahale etmek kaçınılmaz görünüyordu. Sarısözen'in derleme ve icra çalışmaları sırasında halk müziğinin ana karakterinin kaybolmaması için oldukça çaba harcadığı yadsınamaz. Ancak karşısında iki önemli engel vardır. Birincisi, tüm Anadolu'da aynı ses sisteminin kullanılmıyor olmasıdır. İkincisi, Batı nota yazısının batı dışı makamsal ve modal müzikleri yazmak için icat edilmemiş olmasıdır. Aynı sorunu kendisinden önceki derlemeciler de yaşamış ve kendilerince çözüm üretmeye çalışmışlardı. Sözgelimi Saygun, halk ezgilerinin notaya almak için Dr. Suphi Zühtü (Ezgi)'nin 1933-1953 yılları arasında yayınlanan 5 ciltlik "Nazari ve Ameli Türk Musikîsi" başlıklı kitabında ortaya koyduğu ve makamsal müziğin Batı notasyonu ile yazılması için geliştirdiği değiştirgeçleri çok az değişikliklerle kullanmış, ayrıca türkülerin metinlerinde Karadeniz ağzının telaffuzu için bir önceki çalışmasında olduğu gibi çeşitli simlerden (ç yerine ts, c yerine $d z$ vb.) yararlanmıştır (Yükselsin, 2011b: 257). Benzer biçimde Sarısözen'in de bu sorunları aşmak için oldukça çaba harcadığı görülür. Elçi’nin aktardıklarına göre ilk kez Sarısözen, halk müziğindeki koma sesleri numaralandırarak, ezgisel karakterin kaybolmamasına çalışır. "Beş koma bemol koyulduğunda, sanatçı onu iki koma basar. Bu nasıl belli edilecek? Örneğin; halk türkülerini bilmeyen bir sanatçı oradaki beş komayı basar; ancak türküdeki gerekli olan ses basılmamış olur. Biz oradaki koma nisbetini görünce sazımızın perdesini ona göre ayarlayarak basarız." (Elçi, 1997: 123).

Bununla birlikte, Yurttan Sesler tarafından icra edilen türkülerin ait oldukları yerlerden gelen şikâyetler, türkülerin bir şekilde değiştirildiğini gösteriyordu. Açıkça, dinledikleri türküyü ilk kez duyanlar için aslının 0 olduğu algısı gelişirken, türkünün özgününü bilenler bir şeylerin değişmesinin rahatsızlı̆̆ını duyuyorlardı. Radyo Dergisi'nde B.S.E imzası ile yayımlanan ve olasılıkla Baki Süha Ediboğlu tarafından kaleme aldığı düşünülen yazıdan yapılan aşağıdaki alıntı hem bu şikâyetlere bir yanıt hem de 'yetkili uzmanlarca' yapılan müdahalenin meşruluğunun savunulması bakımından dikkat çekicidir. ${ }^{9}$

'Yurttan Sesler' yayınlarında çalınan türküler arasında memleketin çeşitli bölgelerinde söylenen bazı parçaları kısmen değişmiş, yahut -tabir caizse- restore edilmiş şekilde dinleyen bazı kimseler, alışık oldukları nağme ve temaların değişmiş olduğunu görünce sinirleniyorlar: 'bu türkü böyle değildi, bunu bu hale sokan kim, halkın türküsü nasıl değiştirilebilir?' ş̧eklinde itirazlarda bulunuyorlar.

Türk folklorunda öyle türküler vardır ki, Güneyde başka, Kuzeyde başka, Doğu'da başka bir eda ve tavirla okunur. Bunların ana temaları dahi bazen çok değişebilir. Radyo ve radyonun Yurttan Sesler saati bütün memlekete hitap ettiği için bu türküler arasında esaslı bir tercih yapmak, iyisini kötüsünden ayırmak mecburiyeti vardır. (Ediboğlu, 1947: 10).

Ediboğlu'nun 'yetkili uzmanlar' olarak nitelediği 
kişilerden başında Muzaffer Sarısözen gelir. Bununla birlikte, Tekelioğlu'na (1999: 149) göre, “Sarısözen toplanan yerel örnekleri yörelerine göre sınıflayıp notaya geçirirken, âşıkların geliştirdikleri kişisel tarzları yok sayar ve türküyü kendi kafasındaki 'yöreye' göre sınıflandırır: Kriter yedi coğrafi bölgedir ve “uymayan’ örnekler dışlanır”.

\section{Halk Müziğinin Yaygınlaştırılma Aracı olarak Radyo}

'Türk Halk Müziği'nin inşasındaki son adım, derlenen halk müziği gereçlerinin yeniden kurgulanarak tüm yurda öğretilmesidir. Bu süreçte, konservatuvarların yanı sıra radyo da halk müziğinin biçimlendirilmesinde rol oynayan önemli kurumlardan olmuştur. Radyonun bu süreçteki rolü, Ankara ve İstanbul radyolarının devletleştirilmesinden (1936) sonra başlar. İlk yıllarda (1927-1936) özel statüdeki her iki radyoda ağırlıklı olarak Geleneksel Türk Sanat Müziği yayınları yapılmakta olup halk müziği bireysel icralar ve çok kısa sürelerle sınırlıydı. Nihayet cumhuriyet dönemi kültür politikasına görece ters olduğu düşünülen bu durum 1934'de Türk müziğinin devlet eliyle radyolarda yasaklanması ile bütünüyle sonlandırılmıştır. Kocabaşoğlu'ndan (1980: 72) öğrendiklerimize göre, 1927-1936 yılları arasındaki şirket radyoculuğu döneminde radyo yayınlarının hem Ankara hem de İstanbul radyoları genelinde \% 84,25'i müzik yayınlarına ayrıldığı ve bunun yaklaşık \% 44 'lük oranını Geleneksel Türk Sanat Müziği yayınları oluşturduğu halde, Halk müziği yayınları yalnızca İstanbul ile sınırlı idi ve 1927 yılı verilerine göre toplam yayının \% 2'lik bir kısmını oluşturuyordu.

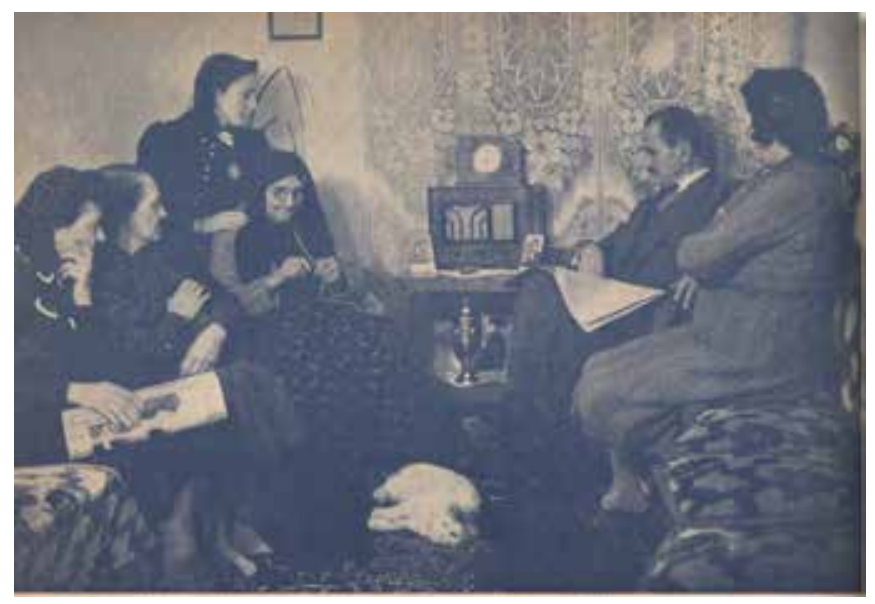

Fotoğraf 2. Radyo başında bir aile, (Radyo, 1942c: arka kapak).
1927 yılında Türkiye Telefon Telsiz Anonim Şirketi (TTTAŞ) tarafından başlayan görece özel radyo yayıncılı̆̆ının (şirket radyoculuğu) ${ }^{10} 1936$ yılında Posta Telgraf Telefon işletmesi'ne (PTT) devredilmesi yoluyla devlet radyosuna dönüştürülmesi, resmi ideolojiye uygun biçimde biçimlendirilmeye başlanılan 'Halk Müziği'nin tüm Türkiye'ye yayılması sürecinin de başlangıcını teşkil eder. 0 döneme kadar, İstanbul ve Ankara radyolarında sistemsiz ve düzensiz olarak yer bulan halk müziği, kısa süre içinde yeni Cumhuriyetin ideolojisine uygun biçimde sistemli ve uzun erimli bir yayınsal içeriğe kavuşacaktır. Ancak, radyonun 1936'da devletleştirilerek Türkçe müzik yayınına yeniden başlanmasının ardından Geleneksel Türk sanat Müziği'nin yeniden icrasına başlanırken, halk müziğinin radyo yayınlarındaki yeri bir süre daha silik kalacaktır. Bu dönemde Ankara Radyosu'nda Sadi Yaver Ataman tarafından gerçekleştirilen 'Açıklamalı Halk Müziği programı, radyolarda anonim ve âşık edebiyatı ürünlerine yer verilen ilk sistemli örnek olması bakımından önem taşır.

Kocabaşoğlu'nun $(1980: 51,54)$ Vakit (3 Ocak ve 4 Şubat 1927) ve Son Posta (6 Kasım 1927) gazetelerinden aktardığına göre, 1927 yılının sonlarında Türkiye'de 2000 kadar radyo alıcısının bulunduğu, bunların yarısının bile kayıtlı ve ruhsatlı olmadığı tahmin edilmektedir. 1930 yılına gelindiğinde TTTAŞ'ye kayıtlı radyo (dolayısı ile abone) sayısı 1500, 1933'de ise 5000 kadardır. Selim Sarper'in (1942:1) Radyo dergisinde yayımlanan yazısında belirttiğine göre, 1941 yılı ortası istatistikleri ile radyo cihazı sayısı evlerde 66.000, Halkodaları, Köy Enstitüleri, kışlalar, orduevleri, lokantalar, kahvehaneler gibi umumî yerlerde 34.000'e ulaşmıştı ve Ankara radyosunun yaklaşık 3 milyon dinleyicisi vardı. ${ }^{11}$

\section{Yurttan Sesler: Yeniden Kurgulanan Homojen 'Halk Müziği'nin Yaygınlaştırılması}

Sarısözen'in derleme çalışmaları ile yurdun farklı bölgelerinden toplanılan türkülerin yeniden kurgulanarak tüm yurda yayılması sürecindeki aracılık rolü 1940 yılında Ankara Radyosu'na çă̆ırılması ile başladı. 0 sıralarda 
Ankara Devlet Konservatuvar'ı Arşiv Müdürü olarak görev yapan Sarısözen'den, Ankara Radyosu Müdürü Vedat Nedim Tör ve Müzik Yayınları Müdürü Mesut Cemil'in teklifiyle, ilk önce Mesut Cemil yönetimindeki Klasik Türk Müziği korosuna (ve elbette radyoları başındaki halka), halk türkülerinin öğretileceği 'Bir Halk Türküsü Öğreniyoruz' programını hazırlaması istenir. Vedat Nedim Tör'ün (1942: 10) 2 yıl sonra Radyo Dergisi'nde yayımlanan sözleri asıl hedefleri net biçimde tanımlar:

‘Bir Halk Türküsü Öğreniyoruz' ve 'Yurttan Sesler' saatleri sayesinde bugün Türkiye'de yüzbinlerin hep bir ağızdan söyleyebilecekleri oldukça zengin bir halk türküsü repertuvarı doğdu..... Milî̀ birliğin en canlı vasıfları dil ve zevk birliği olduğuna göre, şimdiye kadar mahallî kalmış halk türkülerinin bütün millete mal edilişindeki mânâ büyüktür.

Hafta'da iki gün 15'er dakika yayınlanan program, hem radyo dinleyicilerine hem de sanatçılarına her hafta yarım saatlik bir zaman diliminde bir türkü öğretme amacıyla oluşturulmuştur. Oldukça sevilen bu uygulama sonucunda altı ay sonra "Yurttan Sesler" adıyla ayrı bir program daha yapılması kararlaştıııldı. Yurttan sesler ilk başlarda askerlik görevi nedeniyle radyodan ayrılan Sadi Yaver Ataman'ın yürüttüğü açıklamalı halk müziği yayınlarının devamı niteliğindedir. 'Bir Türkü Öğreniyoruz' ve 'Yurttan Sesler' programlarının başlatılmasına kadar radyo yayınlarında yeterli yer bulamayan halk müziği Vedat Nedim Tör'e göre "üvey evlat durumundan kurtulmuş" (Tör, 1999: 54; Yılmaz, 1996: 20), “ilan-ו istiklâl edilmiştir” (Elçi, 1997: 108).

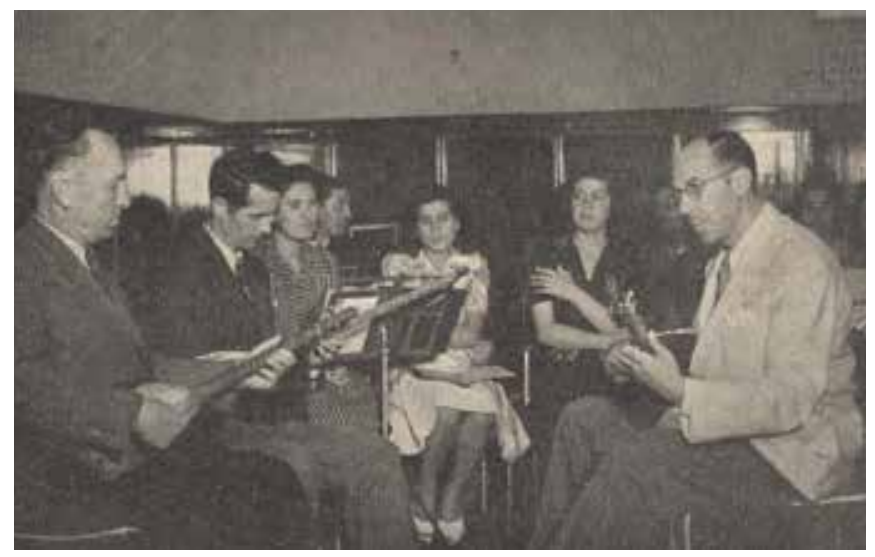

Fotoğraf 3. Yurttan Sesler provada, (Radyo 1942d: 13).
Radyo Dergisi'nin 15 Şubat 1942 tarihli 3üncü sayısında yer alan 'Radyomuzda Halk Musiki Çalışmaları' başlıklı makalede yer alan bilgilere göre, hem 'Bir Halk Türküsü öğreniyoruz' hem de 'Yurttan Sesler' programları için Pazartesi, Çarşamba, Perşembe, Cuma günleri olmak üzere haftada dört gün öğleden sonraları halk müziği çalışmalarına ayrılmıştı. Sarısözen, halk türkülerini koroya öğretirken konservatuvar arşivinden seçip getirdiği yeni türkülerin önce teknik ve biçem/üslûp özelliklerini anlatır, ardından notalarını aktarırdı (Fotoğraf 3). Her koro üyesinin yalnızca halk türkülerini yazmak için kullandığı ayrı bir defteri vardı. Ders aralarında türkülerin notalarını kendi defterlerine yazarlar ve bu defteri sürekli yanlarında bulundururlardı. Notalar ayrıca çoğaltılarak radyo kütüphanesine de konurdu. On beş günde bir yayınlanan program için genel provaların ardından mikrofon önüne en iyi biçimde hazırlanmış olarak çıkılırdı (Radyo, 1942a: 21). Radyo Dergisi'nin 1942 yılı Şubat ayında yayımlanan üçüncü sayısında yer alan haftalık programa göre, haftada iki kez 15’er dakika yayımlanan 'Bir Halk Türküsü Öğreniyoruz/Bir marş öğreniyoruz’ programı Pazartesi ve Çarşamba günleri saat 20:45-21:00 arasında, on beş günde bir 30 dakika yayımlanan 'Yurttan Sesler/Halkevleri Folklor Saati' ise Perşembe saat 19:45-20:15 arasında yayınlanıyordu (Radyo, 1942b: 32).

\section{Öğretilen marș ve türkülerden}
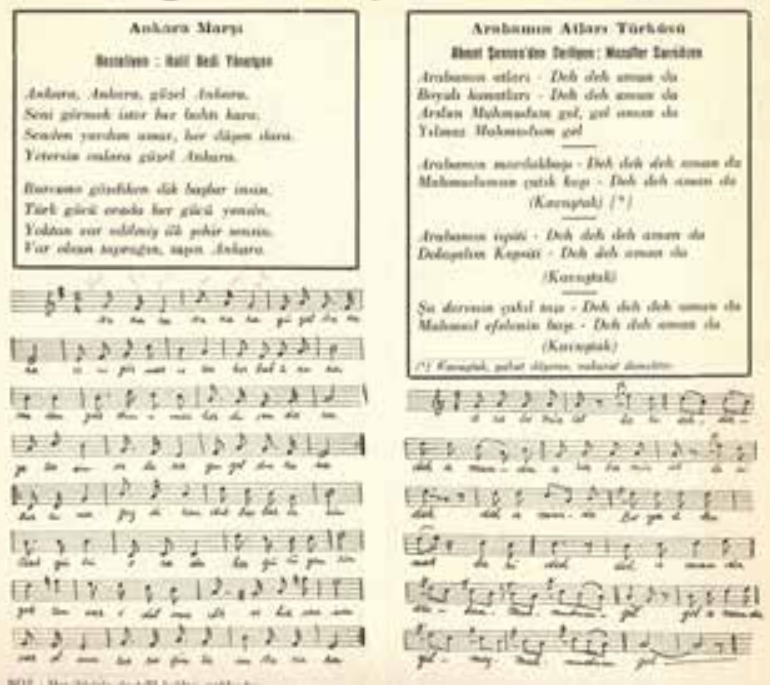

Fotoğraf 4. 'Bir Halk Türküsü Öğreniyoruz/Bir Marş Öğreniyoruz', (Radyo, 1942b: 13). 
Bununla birlikte Geleneksel Türk Sanat Müziği ile Türk Halk Müziği'nin icra özellikleri, ses sistemleri, çalgılar vb. kültürel dizgelerindeki uyuşmazlıklar nedeniyle ayrı bir program yapılması gerekliliği ortaya çıkınca, Yurttan Sesler 1947 yılında küçük ama müstakil bir ekibe dönüştürülür. ${ }^{12}$ Ankara'da oluşturulan modelin 5-6 yıl içinde kazandığı başarının ardından İmir ve İstanbul Radyoları'nda da müstakil Yurttan Sesler koroları kurulur. ${ }^{13}$

Sarısözen, kendisiyle yapılan bir görüşmede (Çeren 1944: 9) $)^{14}$ Yurttan Sesler'in misyonunu şöyle tanımliyordu:

Radyonun sımsıkı tuttuğu ve başardığı halk türküleri yayımı ne sadece dinleyicilerine hoş bir vakit geçirmek ne de yalnız türkülerimizin çeşitleri hakkında fikir vermekten ibaret değildir. Gönüllerimizi bir araya toplamak ve bütün memleketi tek duygu haline getirmek Yurttan Sesler'in başlıca hedefidir. Artık izaha lüzum bile kalmamıştır ki, Yurttan Sesler'in sanatkâr işçileri memlekete en modern tahrip vasıtalarının bile koparamayacağı bambaşka bir istihkâm yapmakla meşguldürler (Çeren, 1944: 9).

Sarısözen'in Yurttan Sesler Korosu ile yaptığı çalışmalar, Sarısözen ne kadar tersi yönde çaba harcamış olsa da halk müziğini tek tipleştirmekten kurtaramamıştır. ${ }^{15}$ Her şeyden önce notaya almak bile türküleri standart bir icra anlayışının içine itiyordu. Bu durum her seferinde farklı icra edilebilen halk ezgilerinin dinamik özelliğine aykırıydı (Balkılıç, 2009: 172). Elçi'ye (1998: 123) göre ise "Halk şarkılarının bu çeşit bir yeniden icadı toplu icra ve söyleme çabalarının sonucudur". Sivas yöresinden derlemeler yapan Vehbi Cem Aşkun'un (1943: 350), dönemin türkü icraları ile ilgili söyledikleri dikkat çekicidir. "Ankara Radyosu'nda Sivas Folklorunu yaşatmak için eski türküleri düzgün, yanlışsız okuyan bir bayan bulamadım. Mevcut saz ve söz ehlinin hepsi de hem ezgileri, hem de demeleri değiştirmişler." (Balkılıç, 2009: 171'den).

Aşkun'un şikâyetindeki haklılığının nedeni aslında o dönemde Sarısözen'in de sıkıntı duyduğu bir konudur. Çünkü o dönemde Yurttan Sesler programda yer alan topluluk aslında Radyo'nun klasik Türk müziği korosu ve onlara eşlik eden birkaç 'çögür' ya da saz/bağlama ustasından başka bir şey değildir. Bununla birlikte 1947'de yalnızca halk müziği icra etmek üzere ayrı kadrolarla kurulmuş 'Yurttan Sesler' korosu da Tokel'in "halk şarkılarının toplu olarak söyleme çabasının, türküler arasındaki nüansları ortadan kaldırdığı” iddiasını çürütemez (Tokel, 2000: 13-133; Balkılıç, 2009: 133'den).

Yurttan Sesler ile başlayan süreç Türkiye'de yeni bir halk müziği icra pratiğinin doğuşunun da başlangıcıdır. 0 döneme kadar çoğunlukla bireysel ve tek bir çalgı eşliğinde icra edilen türküler hem bayan hem erkeklerden kurulu bir koro ile icra edilmeye başlanır. illk başlarda birkaç bağlamadan oluşan çalgı grubuna 1947'den sonra bağlamanın yanına mey, Karadeniz kemençesi vb. çalgıların da eklenmesiyle farklı bir tınısal karakter kazanır. Model Klasik Türk musikisi icrasıyla aynıdır aslında: Çok çalgılı, çok vokalli bir sahne düzeni içinde icra. Hedeflenen şey Anadolu'nun tüm tınısal renklerini ortak bir tınısal biçem içinde toplamaktır elbette. Bu durum bir dereceye kadar kabul edilebilir olsa da dil ve ezgisel müdahaleler yerel müzik dizgelerinin özelliklerini yansıtan müziksel özelliklerin törpülendiği köken kültürden farklı yeni bir halk müziği yaratılmasının önüne geçemez.

\section{Sonuç}

Görüldüğü gibi, erken Cumhuriyet döneminin müzik politikalarının hayata geçirilmesinin hemen her aşamasında görev almış olan Muzaffer Sarısözen'in kültürel aracılığı, bir yandan gönülden bağlı olduğu 'yerel/ köylü müziklerini toplamak ve korumak', öte yandan Cumhuriyet ideolojisinin kültür politikalarına uygun biçimde kendisinden beklenen 'modern', 'Batılı' ölçütlere göre biçimlendirilmiş bir 'Türk Halk Müziği' inşa etme görevini karşılamak üzerine kurulmuştur. Bu nedenle Sarısözen'in kültürel aracılığının birkaç amacı olduğu ve üç aşamadan oluştuğu görülür. Bunlardan birincisi, en çok sahiplendiği ve değer verdiği, görece korumak üzere büyük çaba harcadığı yerel müzikleri toplamak, hem içsel nitelikleri (perde, tartım, tını, oturtum vb.) hem de icra özellikleri (toplu söyleme, çalma, sahne vb.) bakımından bir anlamda modernize etmek. İkincisi, halk müziğini 
devlet erkince meşru kabul edilen ölçütlere (Türklük, ortak değerler, millilik vurgusu yapan vb.) sahip bir 'Türk Halk Müziği’ yaratmak. Üçüncüsü, yeniden inşa edilen 'Türk Halk Müziği'ni başında olduğu 'Yurttan Sesler' topluluğunun icraları ve radyo aracılığı ile tüm Türkiye'ye yaymak.

Sarıözen'in bizzat devlet eliyle kendisine verilen 'aracılık' görevini en iyi biçimde yerine getirdiği açıktır. Çünkü her ne kadar ait olunan kültürel gerçekliği bütünüyle yansıtmasa da, yeni ulus-devlet modeline göre hedeflenen bir 'Türk Halk Müziği' yaratılmış ve kısmen de olsa benimsenmiştir. Ancak, bu müziğin (Türk Halk Müziği) bileşkesinde Anadolu kültürlerine ait unsurların (bölgesel dağar, çalgılar, tür ve üsluplar vb.) tamamının yer almasına çalışıımış ve bölgesel ayrımların (şive, tavır vb.) yansıtılmasına özen gösterilmiştir. Bu çabalara karşın, sonuçta her bir kültürel topluluğun (ya da halkın) müziğe ilişkin içselleştirdiği sosyokültürel dizge ve değerlerin (dinamik, biri diğerinden farklı, yazılı olmayan vb.) dışlandığı, bunun yerine notasyon yoluyla hem zamansal hem de uzamsal olarak sabitlenmiş (örn. İcraya dayalı başkantıların/varyasyonların göz ardı edilmesi) tek bir dile (İstanbul Türkçesi'nin kullanılması) indirgenmiş bir ‘halk müziği’nin yeniden icat edildiği gerçeği değişmemektedir.

\section{Notlar}

1 1926'dan itibaren 'Türk Musikisi' öğreniminin sonlandırılarak yalnızca Batı müziği eğitimi verilmeye başlanılan 'konservatuvarlar'; Batılı/modern çoksesli müzik kültürünün halka öğretecek müzik öğretmenleri yetiştirmek amacıyla kurulan 'Musiki Muallim Mektebi' (1924); 1931'de kapatılan Türk Ocakları'nın yerine kurulan 'halkevleri' (1932); Çoksesli Batı müziğinin seslendirilmesi için kurulan 1934'de kurulan Riyaset-i Cumhur Filarmoni Orkestrası; 1936'dan itibaren devlet tarafından işletilmeye başlanılan 'radyo'; ve 1940'da büyük bir kalkınma ve modernleşme projesi olarak hayata geçirilen 'köy enstitüleri', resmi ideolojiye göre biçimlendirilen 'milli' müzik politikasının devlet eliyle yürütülmesi için kullanılan kurumların başında gelirler.

2 'Kültürel aracılık' modelinin ayrıntıları, daha önceki birkaç çalışmada (Yükselsin, 2011a; Kınlı ve Yükselsin, 2012) görülebilir.

3 Latince medius sözcüğünden türeme olan 'aracılık’ teriminin etimolojik kökeni "yansızlık”, "tarafsızlık”, "bağımsızlık” anlamına da gelmektedir (Runes, 1970: 194).

4 Bochner'e (1981: 2) göre kültür öğrenme sürecinde kuramsal olarak dört ana sonuç mümkündür: (1) Bir kişi, tüm yabancı etkileri reddedip kendi kökeninin kültürüne tutunarak tek kültürlü (monocultural) kalabilir. (2) Bir birey, kendi köken kültürünü reddedip yeni bir kültürü benimseyebilir: sonuç hala tek kültürlü kişidir. (3) Bir birey, köken kültürünü elinde tutarak ikinci bir kültürü de öğrenerek iki-kültürlü (bicultural) olabilir. (4) Nihayet, bir birey köken kültürünü elinde tutup diğer birkaç kültürü öğrenerek çok-kültürlü (multicultural) olabilir (Yükselsin, 2011a: 225,226'dan).

5 Elçi (1997: 23), Sarısözen'in Sivas'daki yetişme sürecinde nota ve kulak eğitimi aldığını belirtse de buna ilişkin somut verilere rastlanmamıştır.

6 Sarısözen'in İstanbul Belediye Konservatuvarı'ndaki eğitim süresi, Şenel'in "Cumhuriyet Dönemi Türk Halk Müziği Araştırmaları" başlıklı makalesinde (1999: 109) "3 yıl kadar”, Altınay'ın yüksek lisans tezinde (2008: 1) "iki yıl” olarak belirtilmektedir. Ancak, Muzaffer Sarısözen'in ölümünün 50'nci yılı nedeni ile düzenlenen sempozyumda (17-21 Kasım 2013, Sivas) yapmış olduğum sunum sırasında Süleyman Şenel araya girerek Sarısözen'in 3 yıl okumadığını kısa süreli bir sertifika eğitimi aldığını vurgulamış, Sarısözen'in oğlu Memil Sarısözen de bu ifadeyi doğrulamıştır.

7 İstanbul Belediye Konservatuvarı (eski adıyla Dârl'ülElhan) tarafından halk müziği alanında gerçekleştirilen derleme çalışmalarını incelediğimizde bunların üç aşamada gerçekleştirildiği görülür. 'Uzaktan derleme' olarak da adlandırılabilecek birinci aşamada Türkiye'nin çeşitli yerlerine yazılan mektuplarla türkülerin notaya alınarak gönderilmesi istenir ve gelenler elden geçirilerek yayınlanır. 1922-1925 yılları arasında her ilin Milli Eğitim Müdürlükleri aracılığıyla Anadolu'nun çeşitli yerlerinde görev yapan köy öğretmenleri, müzik öğretmenleri, mahalli müzisyenler, muhtarlar, sağlık görevlileri vb. ilgililere gönderilen sorukağıdı/anket içeren bir mektup yoluyla gerçekleştirilen çaısşmanın sonuçları 1926 yılından itibaren yayımlanmaya başlar (Altınay, 2008: 3; Şenel, 1999: 106, 107). İkinci aşamada ise bu çalışma tarzındaki yanlışığın farkına varılır ve bir heyet ile derleme gezilerine çıkılarak türküler bizzat yerinde notaya alınır. Bu saptama aşamasında bir bölümü fonografa kaydedilirken, bir bölümü de yerinde notaya alınarak derlenir. 1926-29 yılları arasında düzenlenen 4 derleme gezisinin ardından 850 türkü derlendi (Hasgül, 1996: 35). Bu derleme gezilerinde başta Rauf Yekta, Yusuf Ziya Demirci, Besim Tektaş, Dürri Turan olmak üzere Muhiddin Sadak, Ferruh Arsunar, Mahmut Ragip Gazimihal, Remzi Bey, görev aldılar (Altınay, 2008: 11-13; Şenel, 1999: 108; ÜlkütaŞır, 1973: 32-33).

8 Ankara Konservatuvarı tarafından gerçekleştirilen derleme gezilerine katılan diğer isimler Mahmut Ragıp Gazimihal, Hasan Ferit Alnar, Necil Kazım Akses, Ulvi Cemal Erkin, Nurullah Şevket Taşkıran ve Arif Etikan'dır (Elçi, 1997:16).

9 Kaynaklarda (Balkılıç, 2009; Şenel, 1999) Radyo 1947 olarak atıfta bulunulan bu makalenin yazarı olduğunun düşünülmesinin nedeni, Aynı ciltteki sayıların taranması sonucunda Baki Süha Ediboğlu adına rastlanmasıdır.

10 Kocabaşoğlu'nun (1980: 11) aktardığına göre, Türkiye'deki ilk radyo yayın denemeleri 1921-23 yılları arasında yapılmıştır. Bununla birlikte asıl sistematik radyo yayını Cumhuriyet Hükümeti’nin 1925 yılında çıkardığı 'Telsiz Tesisi Hakkında Kanun" uyarınca 1926'da temelleri atılan İstanbul 
ve Ankara vericilerinin tamamlanmasının ardından 8 Eylül 1926'da imzalanan anlaşma ile TTTAŞ'ye verilen Ruhsatname ile başlar. Anlaşma, İçişleri Bakanı Cemil Uybaydın, İ̧̧ Bankası Genel Müdürü Mahmut Celal Bayar, Anadolu Ajansı Yönetim Kurulu'ndan Falih Rıfkı Atay ve Sedat Nuri Illeri arasında imzalanmıştır. Otuz üç maddeden oluşan anlaşma ile Ankara ve İstanbul'da kurulan vericilerin işletilmesi 10 yıl süre ile şirkete devredilmiştir. 6 0cak 1926'da kuruluşu Hükümetçe onaylanan şirketin "Nizamname-i Dahili" adlı sözleşmesinde belirtildiğine göre şirket sermayesinin \% 40' ו (60.000 TL.) İş Bankası'nın, \% 30’u (45.000 TL.) Anadolu Ajansının ve \%30'u (45.000 TL.) da eşit paylar halinde Bolu milletvekili Falih Rıfkı Atay, Gümüşhane milletvekili Cemal Hüsnü Taray ve tüccar Sedat Nuri Illeri'nindir (Kocabaşoğlu, 1980: 11-13).

111944 yılına gelindiğinde Ankara Radyosu'nda iki yayım kanalı bulunmaktaydı: Türkiye Radyosu (uzun dalga) ve Ankara Radyosu (kısa dalga). Yurttan Sesler programının da aralarında bulunduğu tüm yayınlar saat 07:30-22:45 saatleri arasında yayım yapan Türkiye Radyosu'nda yayımlanmaktaydı (Radyo, 1944: iç kapak).

12 Muzaffer Sarısözen'in şefliğinde 1947'de ayrı bir topluluk olarak oluşturulan Yurttan Sesler korosunun ilk çekirdek kadrosu çalgılarda (bağlamalar) Sarı Recep, Ahmet Gazi Ayhan, Mucip Arcıman; kadın seslerinde Neriman Altındağ, Muzaffer Kıvılcım, Sabahat Karakuş; erkek seslerinde Ali Can, Nurettin Çamlıdağ ve Turhan Karabulut'dan oluşuyordu (Şenel, 1999: 117).

13 İzmir Belediyesi tarafından 1949 yılında Kültürpark içinde kurulan İzmir Radyosu'nun 1953'de devlet radyosuna dönüşmesinin ardından Sarısözen, ikinci Yurttan Sesler koro sunu İzmir'de kurarak başına Mustafa Hoşsu'yu atar. 1954'de İstanbul'da kurduğu Yurttan Sesler'i 3 ay süreyle çalıştırdıktan sonra Ahmet Yamacı'ya devreder (Elçi, 1997: 109).

14 Şenel (1999:117)'de Sarıözen'in Radyo Dergisi'ne verdiği demeç 1942 olarak tarihlendirilmektedir. Doğrusu 1944'dür ve Sarısözen ile görüşme yapıp yayınlayan Şerif Sait Çeren'dir (Çeren, 1944: 9)

15 Sarısözen, Türk Halk Müziği'nin inşası ve yaygınlaştırılmasına radyodaki görevinin yanı sıra yayınlanan üç kitabı ile de katkıda bulunmuştur. Radyo'da göreve başladıktan bir yıl sonra (1941) 'Seçme Köy Şarkıları' kitabı yayımlanır. 1952 yılında yayımlanan Yurttan Sesler başlıklı ikinci kitabı, birincisinde olduğu gibi halk müziğinin eğitim kurumlarında yaygınlaştırılması için kaynak niteliğindedir. Kitapta 70 türkü ve Bar, Zeybek, Halay, Oyun havası türündeki 14 çalgısal halk müziği yer almaktadır. Sarısözen'in son basılı çalışması olan ve ölümünden bir yıl önce (1962) yayımlanan 'Türk Halk Musikisi Usulleri', önsözünde de (1962: 2) belirttiği gibi Ankara Devlet Konservatuvarı'ndaki 'Müzik Folkloru' dersi için hazırladığı notların bir araya getirilmesinden oluşmuştur.

\section{Kaynakça}

Altınay, F. Reyhan (1993). Muzaffer Sarısözen'in Hayatı ve Türk Halk Müziğine Katkıları, Yayımlanmamış Yüksek Lisans Tezi, Ege Üniversitesi Sosyal Bilimler Enstitüsü Temel Bilimler Anabilim Dalı, İzmir.

Aşkun, V. Cem (1943). Sivas Folkloru, Cilt II, Sivas: Kamil Matbaası.

Balkılıç, Özgür (2009). Cumhuriyet, Halk ve Müzik: Türkiye'de Müzik Reformu 1922-1952, Ankara: Tan Kitabevi Yayınları.

Bochner, Stephen (1981). "The Social Psychology of Cultural Mediation”, The Mediating Person: Bridges Between Cultures, Ed: Stephen Bochner, G K Hall \& Co, pp:6-36.

Çeren, Şerif Sait (1944). “Bir Konuşma”, Radyo, 3(31): 9.

Debrix, François (2003). "Introduction: Rituals of Mediation", Rituals of Mediation: International Politics and Social Meaning, Ed: François Debrix and Cynthia Weber, Minneapolis: University of Minnesota Press, pp: xxi-xlii.

Ediboğlu, Baki S. (1947). "Yurttan Sesler”, Radyo, 6(65): 10.

Elçi, Armağan C. (1997). Muzaffer Sarısözen: Hayatı, Eserleri ve Çalışmaları, Ankara: Kültür Bakanlığı Yayınları.

Gökalp, Ziya (1972). Türkçülüğün Esasları, Ankara: Milli Eğitim Basımevi.

Hasgül, Necdet. 1996. Cumhuriyet Dönemi Müzik Politikaları", Folklora Doğru: Dans, Müzik, Kültür, 62: 27-48.

Kınlı, H. Devrim ve Yükselsin, İbrahim Y. (2012). “Kültürel Aracılığın Ritüelleri: Bergamalı Profesyonel Roman Müzisyenlerin Geçiş Ritüellerindeki Aracılık Rolleri”, III. Hisarlı Ahmet Sempozyumu, s: $432-446$.

Kocabaşoğlu, Uygur (1980). Şirket Telsizinden Devlet Radyosuna: TRT Öncesi Dönemde Radyonun Tarihsel Gelişimi ve Türk Siyasal Hayatı İçindeki Yeri, Ankara: Ankara Üniversitesi Siyasal Bilgiler Fakültesi Yayınları; 2010 İstanbul: Illetişim Yayınevi.

Radyo, (1942a. "Radyomuzda Halk Musikî Çalışmaları”, Radyo, 1(3): 21.

(1942b). “Öğretilen Marş ve Türkülerden”, Radyo, 1(3): 29.

(1942c). "Bir Haftalık Neşriyat Programı Kalıbı”, Radyo, 1(3): 32

(1942d). “Yurttan Sesler”, Radyo, 1(10): 13

Reinhard, Kurt (1991). “Sonsöz”. Küçük Asya'dan Türk Halk Musikisi. Çev. Bülent Aksoy. İstanbul: Pan Yay. s. 217-228.

Runes, Dagobert (1970). Dictionary of Philosophy, Totowa, N.J.: Littlefield, Ad-fams \& Co.

Sarper, Selim (1942). “Ankara Radyosu Milletin Emrinde”, Radyo, 1(2): 1

Sarısözen, Muzaffer (1941). Seçme Köy Şarkıları, İstanbul: Remzi Kitabevi.

(1952). Yurttan Sesler, Ankara: Akın Matbaası.

(1962). Türk Halk Musikisi Usulleri, Ankara: Resimli Posta Matbaası. 
Şenel, Süleyman (1999). “Cumhuriyet Dönemi'nde Türk Halk Müziği Araştırmaları”, Folklor/Edebiyat, 17: 99-128.

Taft, Ronald (1981). "The Role and Personality of the Mediator", The Mediating Person: Bridges Between Cultures, Ed: Stephen Bochner, G K Hall \& Co, pp: 53-88.

Tekelioğlu, Orhan (1999). “Ciddi Müzikten Popüler Müziği Musiki Inkılabının Sonuçları”, Cumhuriyet'in Sesleri içinde, der. G. Paçacı. İstanbul: Tarih Vakfı Yayınları, s:146-153.

Tokel, Bayram B. (2000). Neşet Ertaş Kitabı, Ankara: Akçağ Yayınları.

Tör, V. Nedim (1942). “Halk Türküleri”, Radyo, 1(7): 10.

(1999). Yıllar Böyle Geçti, İstanbul: Yapı Kredi Yayınları.

Üstel, Füsun (1994). “1920'li ve 30’lu Yıllarda 'Millî Musiki' ve 'Mûsıkî İnkılabı'”, Defter, Sonbahar, Sayı 22, İstanbul: Metis Yayınları, s.41-44; Ayrıca Cumhuriyet'in Sesleri içinde, der. G. Paçacı. İstanbul: Tarih Vakfı Yayınları, s: 40-49.

Yılmaz, Niyazi (1996). Türk Halk Müziğinin Kurucu Hocası Muzaffer Sarısözen, Ankara: Ocak Yayınları.

Yükselsin, İbrahim Y. (2011a). "Kültürel Aracılık, Romanlar (Çingeneler) ve Müzik: Bir Rumeli Ezgisinin Kırkpınar Güreş Havasına Dönüştürülmesi Örnekolayı”, 2. Ulusal Hisarlı Ahmet Sempozyumu Bildirileri, ed: Çağhan Adar \& Yunus E. Uygur, Kütahya: Güzel Sanatlar Derneği Yayını, s: 221-241.

(2011b). "Etnomüzikoloji Açısından Ahmed Adnan Saygun”, Bilig: Türk Dünyası Sosyal Bilimler Dergisi, 27: 247277.

\section{Görsel Kaynaklar}

Fotoğraf 1. Muzaffer Sarısözen, M. Ragıp Gazimihal, Rıza Yetişen derleme çalışmasında, 1939/40.

Fotoğraf 2. Radyo başında bir aile, (Radyo, 1942c: arka kapak).

Fotoğraf 3. Yurttan Sesler provada, (Radyo 1942d: 13).

Fotoğraf 4. 'Bir Halk Türküsü Öğreniyoruz/Bir Marş Öğreniyoruz', (Radyo, 1942b: 13). 